\title{
Mediated education in early modern travel stories: How travel stories contribute to children's empirical learning
}

\author{
Feike Dietz \\ Utrecht University \\ Email: F.M.Dietz@uu.nl
}

\begin{abstract}
Argument
Linking up with recent studies on the experience of space and place in modern youth literature, this article analyzes how the "journey" as a narrative line and motif transformed Dutch early modern travel books for children from classical teaching instruments into explorative knowledge places. In the popular seventeenthcentury Glorious and Fortunate Journey to the Holy Land, young readers were invited to travel within the book, which was presented as a place that covers material pages to observe as well as imagined places to read about. Eighteenth-century travel books, for example written by Joachim Heinrich Campe, shifted from an inner to an empirical mode of travelling. They raised the suggestion that they offered unmediated observations and travel experiences, as if reading about places was equal to seeing places. Since travel literature facilitated active knowledge quisition among youngsters, but also left little room for autonomous innovations or different interpretations, this article reveals the emancipatory as well as restrictive character of such places of learning. By turning reading into a kind of travelling, travel books served as a substitute for travel.
\end{abstract}

Keywords: Youth literature; travel stories; empirical learning; knowledge production; education

\section{Introduction}

Early modern travel books for children functioned as places for learning: as physical objects that a child might hold on and look at, they represented to their readers fictional places which young readers were to explore to gain new knowledge, as well as telling stories readers were to imitate to become knowledge-producing. By analyzing these learning places in detail, this paper helps us to reveal the educational potential of early modern media practices on a more general level: how and to what extent did media contribute to children's empirical learning?

With regard to adults, it has been generally assumed that the early modern knowledge culture increasingly depended on an active, empirical mode of producing knowledge, and on the capacity to explore their own environment: scholars as well as craftsmen acquired knowledge from empirical experiences and observations (Smith 2009; Van Miert 2013; Harkness 2007; Cook 2007). At first sight, this ideal of knowledge production seems to be incompatible with books as classical teaching instruments and transmitters of cut-and-dried information. But during the past decade, historians of science convincingly argued that books actively stimulated new knowledge production among readers and authors (Smith and Schmidt 2007; Frasca-Spada and Jardine 2000), and that textual and visual media helped people to improve their knowledge competences, for example by visualizing hands-on skills or by demonstrating sensual knowledge practices (Smith and Beentjes 2010; Smith 2004; Ogilvie 2006; Kusukawa 2012).

\footnotetext{
(C) The Author(s) 2019. This is an Open Access article, distributed under the terms of the Creative Commons Attribution licence (http:// creativecommons.org/licenses/by/4.0/), which permits unrestricted re-use, distribution, and reproduction in any medium, provided the original work is properly cited.
} 
I turn to the general question on how youngsters were involved in such mediated empirical learning practices. It has been known that the ideal of active, empirical knowledge production impacted on new pedagogical ideals. Locke's and Rousseau's Enlightened pedagogical tracts, written to stimulate explorative learning practices, are the most convincing examples of this tendency, but somehow comparable pleas were spread by earlier humanists as well: Erasmus struggled against authoritative teachers and promoted forms of practical learning (Erasmus 2006). At the same time, however, the early modern "politics of age" put youths in a subordinate position and turned them into objects to regulate instead of independent innovators (Griffiths 1996). And while Enlightened pedagogues recognized the innovative capacity of the young, the growing pedagogical interest simultaneously spurred the anxiety for the children's development and the need to keep youths from doing wrong (Baggerman 2004).

So, we face an intriguing paradox here: a plea for an active and searching mode of learning went hand in hand with the strong tendency to guide and discipline youths. Early modern catechists, for example, criticized the traditional learning style of memorization and passive repetition of religious dogmas, but at the same time aimed to control the youngsters' learning process (Dietz 2016). Stronks' paper within this thematic issue, focusing on the representation and discourse of youthful curiosity in the early modern textual culture, highlights a comparable ambivalent approach towards empirical learning practices among the young. While the traditional educational models clashed with new pedagogical ideals, learning youths remained largely related to docility and memorization: while "curiosity turned ... to a virtue in the adult world," this "was not the case for the early modern youth," Stronks states in her general argument.

This paradox impacted on the tradition of Western-European youth literature. Current research generally emphasizes the disciplining, didactical character of children's books: they often functioned as (straightforward) instruments of moral instruction (Brown 2009; Grenby 2011; Buijnsters 1989). At the same time, however, they intended to create self-regulating, active subjects: Nina Christensen for example analyzed how Danish youth magazines stimulated young readers "to be curious, eager to learn, able to reason," and depicted its "child characters ... as wiser, more sensible, and better writers than adults" (Christensen 2009, 199). Children's books were also used as tools to introduce young generations to new knowledge and current knowledge practices (Fyfe 2000): John Newbery's popular Newtonian System of Philosophy Adapted to the Capacities of Young Gentlemen and Ladies (1761), for example, offered a child's introduction to Newtonian science (Secord 1985).

This article contributes to our understanding of the book as a medium to serve both purposes: how did the children's book succeed in combining the ideal of empirical, explorative learning with the need for guidance and unambiguous teaching? I particularly focus on Dutch travel books for children from the seventeenth and eighteenth centuries, to analyze the way they both created and restricted spaces to explore and appropriate. The article builds on current research on the experience of space in contemporary youth literature, which often justifies itself by stressing the topicality of the theme: in our globalizing world, youngsters need to deal with shifting borders and complex interactions between the global and the local (Doughly and Thompson 2011; Cutter-Mackenzie, et al. 2014). This globalization problem was just as pressing in the early modern Netherlands that were heavily involved in the development of international trading markets, expanding borders, and the travelling of many migrants.

But although significant, the early modern Dutch case has remained understudied for the most part. The mass of travel literature produced in the Netherlands has been largely studied (Barendvan Haeften 1992; Enenkel, et al. 1998; Meijer Drees 1997; Gelderblom 2006; Roeper and Wildeman 1997), but children as intended readers have been given little attention, while scholars in the field of children's culture merely focused on travel stories from the nineteenth century and their intertextual relationship to travel books for adults (Parlevliet 2009; 
Parlevliet 2014; Bekkering 2003; Harms 2014; Harms 2012; Beening 1996). ${ }^{1}$ In the international scholarship on (travel) books for the young, the Dutch case is completely lacking. This article, for example, is the first effort to present the Dutch translation of Joachim Heinrich Campe's Robinson der Jungere (1779) to an international audience and as such enriches the scholarly discussion on the lively reception of Campe's Robinson Crusoe adaptation (O'Malley 2012). While the significance of this article is closely related to its focus on the unknown Dutch case, the insights we gain by analyzing Dutch sources could not be interpreted as "typically Dutch": since children's travel books crossed national boundaries, this paper will trace what might best be characterized as Western European developments in early modern youngsters' places for learning, reading and travelling.

I focus on travel literature for young child readers. My corpus will not include, for example, adaptations of Fénelon's famous Les aventures de Télémaque [The adventures of Telemachus] 1699 (Schmitt-Maa $\beta$, et al. 2014), which was read by older youths, and was only adapted to Dutch schoolchildren in the course of the nineteenth century (Martin 1928, 49, 55-59). In the case of adolescents, it has already been known that early modern processes of travelling and reading (travel stories) were highly interwoven: Grand Tour travelers consulted books before, during, and after their travelling, to explore new places as well as to absorb or recall their experiences (Ansell 2018; Verhoeven 2004). This does not apply automatically to young children, who usually did not travel on their own, but actually had the opportunity to become fellow travelers while reading books. The young Otto van Eck, who we know from the diary he kept from his eleventh year till he was eighteen, did not travel beyond Kampen (around 150 kilometers away from home), but read stories about travelers who explored America and Africa (Baggerman and Dekker 2005, 196, 310, 317). Parents and educators often praised such instructive substitutes for physical travelling. In Margareta Geertruid de Cambon-van der Werken's youth novel De kleine Klarissa (1790), Sophia's mother praised her virtuous and inquisitive daughter who often consumed travel literature (De Cambon-van der Werken 1790, 53).

This article seeks to understand how travel books for children functioned to spur the development of young, knowledgeable selves. Uncovering actual reading processes is admittedly very difficult: for example, none of the eighteenth-century Dutch copies of Robinson Crusoe kept in public and academic libraries, contain juvenile marginalia. ${ }^{2}$ But my analytical model - aimed at analyzing the construction of places as well as interwoven processes of "reading about" and "seeing" - indeed offers me the opportunity to reveal how these travel books were intended to be used, and helps me to trace a development in the way they functioned. In the seventeenth century, the child's space was restricted by the medium of the book: the travel motif above all functioned as an invitation to explore the materiality of the book. The eighteenth century shifted from an inner to a more empirical mode of travelling. Travel stories introduced several narrative techniques stimulating young readers to travel along with the travelers and to accept their fictional journey as a reality. Since travel stories turned reading into a kind of travelling and discovering knowledge, they served as substitutes for empirical experiences. As such they invited children to develop their own competencies to construct places, while they simultaneously restricted the child's exploratory expedition and prescribed the knowledge and ideas they acquire. So, the "journey" as a narrative line and motif transformed books from classical teaching instruments, but also impeded the readers' own exploration of empirical worlds and hampered the autonomous shaping of the knowledgeable self.

\footnotetext{
${ }^{1}$ Sanne Parlevliet and others mapped the appropriation of famous travel stories by children's books and prints, particularly focusing on Gulliver's travels, Robinson Crusoe's imagined journey, the hibernation on Nova Zembla and the adventures of Bontekoe.

${ }^{2}$ I have used the Short Title Catalogue Netherlands, and checked digitalized copies (Google Books, www. Delpher.nl) as well as copies kept in libraries and archives. I would like to thank colleagues of the Royal Library in the Hague, Leiden University Library, and Haarlem City Library for helping me figure this out.
} 


\section{Reading Places in Travel Stories for Children: Theoretical Framework}

My analytic approach is indebted to current research on modern youth literature and early modern travel books. This paper especially links up with some recent studies on the experience of space and place in youth literature (Cutter-Mackenzie, et al. 2014; Doughly and Thompson 2011; Carroll 2012; Cecire, et al. 2015). These studies could be considered as part of a broader "spatial turn" in cultural and social studies: a scholarly trend which demands us to rethink the geographical character of human beings, actions, and knowledge (e.g. Tally 2013; Tally 2011; Crang and Thrift 2000). In Homo Geographicus (1997), an important introduction to the philosophy and theory of geography, Robert Sack made scholars aware of the mutual process of having control over and being controlled by space: "Our geographical nature shapes our world and ourselves" (Sack 1997, 1). According to Sack, we as human beings transform geographical spaces into our own places, while these owned places in their turn structure our lives and actions, determine our conceptions, and guide our moral reflections. Literary scholars build on such observations when they approach language as a system structured and empowered by spatial relations and actions and read literature as a form of mapping (social, geographical, imaginative) spaces (Tally 2013; Crang and Thrift 2000). With regard to the early modern period, Tom Conley interpreted early modern French poetry and imagery as instruments to map and shape the outside world: "the poet's vision is much like that of the topographer who sees, discerns, and orders the world in consort with the art of illustration." Conley considers the poet to be a cartographer "insofar as it is his or her task to describe the world by mixing images, visual designs, and both aural and optical traits of language" (Conley 2011,3). This mediated creation of spaces, as Conley argues, contributed to the formation of subjects in early modern times, since "the self would acquire its identity through the creation of a space that bears the presence or the reminder of the mapping of its signature" (Conley 1996, 2). Also focusing on Renaissance French poetry, Louisa MacKenzie explored how geographical literature attaches significance to landscapes and connects physical to mental spaces (MacKenzie 2011).

This paper turns to the experience of place in early modern Dutch children's travel literature. Following Conley and MacKenzie, I aim to understand how these travel books merged imagined places and readers' mental spaces and shaped a self. While Conley primarily focuses on poets as cartographers, I concentrate on the reader and his/her capacity to interact with the surrounding world while reading travel books. I aim to understand how youngsters were faced with the perceptions and experiences of travelling protagonists and were invited to use them in their process of knowledge acquisition.

In my analysis of these spatial representations, I follow the often-defined distinction between "space" and "place," and between "reading about" and "seeing" places. Following many theorists of spatiality, such as Robert Sack (1997) and Tim Cresswell (2004), space denotes "a property of the natural world" (Sack 1997, 16) and "the raw material before becoming place" (MacKenzie 2011, 24). Place, on the other hand, is the experience, activity, and appropriation of space: a place is a meaningful location constructed by people and media:

Place implies space, and each home is a place in space. Space is a property of the natural world, but it can be experienced. From the perspective of experience, place differs from space in terms of familiarity and time. A place requires human agency, is something that may take time to know, and a home especially so. As we move along the world the earth we pass from one place to another. But if we move quickly the places blur; we lose track of their qualities, and they may coalesce into the sense that we are moving through space. (Sack 1997, 16)

Michel de Certeau and Henri Lefèbvre, whose critique of everyday life has been so influential, use these two concepts as well, but in the opposite way (Certeau 1984, 111; Lefèbvre 1991). While following Sack's and Creswell's conceptualization of place as the constructed space, I also use 
Lefèbvre's idea of legibility: places are created products that "can be decoded, can be read" (Lefèbvre [1974] 1991, 17; emphasis in the original). I consider travel literature as a means for constructing places accessible for young readers who need to take up the challenge to read and decode them.

Places could be produced and decoded through connected processes of "reading about" and "seeing." In an essay on the metaphor of "reading spaces and places," Brian Stock argues that the activities of seeing and reading are fundamentally different but often linked to each other.

"Suppose I want to see the Taj Majal. I can go to Agra and see it; or, if I do not have the means, I can read about it and look at an illustrated guidebook. In each case, I have different visual experiences of the monument and, in some sense, both can be called readings" (Stock 1993, 319). Each type of reading has its own restrictions: "Not knowing the text, I cannot reconstruct the architectural allusions in the place; but, using a guidebook alone, I cannot reconstruct the experiences within its non-narrative setting on the Agra river" (ibid.). That is why reading and seeing depend on one another for understanding spaces.

It does not matter, then, whether I look at the Taj, then read about it, or read about it, then look at it. In each case, something implicitly read is necessary for my understanding; and, while I am looking at the monument, or thinking about it visually, I conveniently forget about what is read. I see a readerly whole, but I have read the Taj only in part. To return to my point: metaphors of reading both reveal and conceal, and they do so through an "interaction" that makes one element the framework of the other. (ibid., 319-320)

Children's reading of travel stories could be defined, of course, as a process of "reading about" created places, but sometimes also functions as an invitation to "see" places within and beyond the book. This article analyzes the construction of places by both travelers in and readers of travel books for children, and as such aims to understand how this process changed over the years and stimulated the youngsters' identity formation. The construction of places is often analyzed in relation to processes of identity formation: according to Doughly and Thompson in Knowing Their Place (2011), “children's literature addresses the processes of coming both to know oneself as situated in space and how the spaces one inhabits shape one's self" (ibid., 1). I build on this perspective, while particularly focusing on the creation of a "knowledgeable self," i.e., someone who is able to appropriate, acquire, and assess knowledge.

\section{Mental Traveling in the Seventeenth Century}

According to Piet Buijnsters, a specialist in Dutch youth literature, travel stories for children became a subgenre in the last decades of the eighteenth century (Buijnsters 1989, 211; Salman 2000, 82). However, the first - and for a long time only - travel book for children's education was published no less than 150 years before: Heerlycke ende geluckige reyse naer het Heyligh Landt ende de stadt van Jerusalem [Glorious and Fortunate Journey to the Holy Land and the City of Jerusalem] c. 1634. This popular and often reprinted travel book derived from the long tradition of pilgrim literature, which slowly disappeared after the Reformation but was still adapted for the use of school children in the first half of the seventeenth century (Wasser 2014, 23-24, 240-1; Van Toorn, Spies and Hoogerhuis 1989, 161-165). In the Heerlycke ende geluckige reyse, the Antwerp father Jan van der Linden described his pilgrimage to Jerusalem from 1633, accompanied by Alexian brothers (brothers of a Catholic congregation, originating in communities of beguines and beghards). ${ }^{3}$ On the title page, Van der Linden introduced his book as an instrument for the improvement and amusement of youth. He dedicated his book to a couple of Antwerp schoolmasters and principals, urging them to give their "green young" this Heerlycke ende geluckige reyse

${ }^{3}$ The fathers set out on their journey in 1633 ; dedication dated "1634." 
"instead of other fabulous books, with which the schools are often full" (Van der Linden s.d., A1v, A2). ${ }^{4}$ In his dedication, Van der Linden characterized his book as a true (instead of invented) story, and suggested that empirical experiences could instruct.

In the Heerlycke ende geluckige reyse, places are discovered by travelers who integrate two ways of reading: Van der Linden and his fellow travelers observe their environment by using their eyes ("seeing"), and consult texts about them ("reading about") - comparable to Stock's Taj Mahal visitor discussed in the previous section (Stock 1993, 319-200). When the depicted travelers visit the Mount of Olives, they first of all explore their space by using their eyes: careful textual depictions contain many explicit visual and sensual expressions ("they saw," "they shew," et cetera):

On the Mount of Olives, there are dilapidated houses, where it is said Mary Magdalene would have lived, and that it once had been a church. They first show a yellowish stone, where Martha came towards Christ. At this, people see the ruins of a Cloister, which has been built in honour of Mary Magdalene. Not far from here is the town of Bethany on the other side of the Mount of Olives, a small mile from Jerusalem, but all you can see there are some huts of the Moors. (Van der Linden s.d., 40; emphasis added) ${ }^{5}$

The Mount of Olives provokes the travelers to read Biblical texts depicting the visited place: "Here, the Alexian brothers read from the gospel about Lazarus's resurrection, with the following prayers" (Van der Linden s.d., XX). ${ }^{6}$ The observations and readings became fundamentally interwoven, particularly when the fathers visit spaces consisting of words or letters: they encounter for example "around twenty Letters" in an empty church (Van der Linden s.d., 20, 30). And these integrated modes of reading contribute to the development of several types of knowledge: they not only stimulated religious knowledge, but also spurred on topographical as well as historical knowledge, practical knowledge (how to behave as a Christian, how to practice religion), and interpretative knowledge (how to understand the Bible, how to relate Biblical texts and prayers to physical places and observations).

By means of the book as the materialized journey, young readers of the Heerlycke ende geluckige reyse are able to follow in the fathers' footsteps. While the fathers read about the Mount of Olives they visit, children have the opportunity to read about the places traveled by the fathers. The fathers' process of "seeing," however, is now shifted towards the book as a constructed place: the material book, instead of the empirical environment, is the object of their observation. This book consists of several typefaces and images along with the texts, aiming to familiarize children with different signs and literacies, and inviting the reader to explore the book as a dynamic place. In case of the Mount of Olives, children read the many textual observations and simultaneously observe the described places in a picture, marked by several letters (fig. 1). Such "lettered images" were commonly used in devotional books at the time, in which illustrations served as instruments to spur the reader's imagination and inner development. In popular Jesuit meditation books such as Jerome Nadal's Evangelicae historiae imagines (1593) and Antoine Sucquet's Via vitae aeternae (1620), letters were integrated within the engravings, to mark pictorial elements, connect them to textual descriptions, and thus structure the reader's meditation process. Meditative readers of

\footnotetext{
${ }^{4}$ Original Dutch text: "groene Jonkheyd”; "in plaetze van andere fabuleuze Boeken daer dikwils de Schoolen vol van zyn."

${ }^{5}$ Original Dutch text: "Over den Berg van Oliveten staen noch vervallingen daer men segt dat Maria Magdalena soude gewoont hebben, en heeft een kercke geweest: eerst toonden-ze eenen geelachtigen steen, daer Martha Christus te gemoet gekomen is: hier by siet men ruinen van een Clooster, dat ter eeren van Maria Magdalena getimmert is geweest: niet verre van hier lacht de stadt Bethenien te staen op d'ander zijde van den Olijf-berg, een kleyn myle van Jerusalem, maer en is niet te sien dan weynige huttekens van Mooren."

${ }^{6}$ Original Dutch text: "Hier lasen de Minder-broeders het Evangelie van Lazarus verweckinge met de navolgende gebeden."
} 


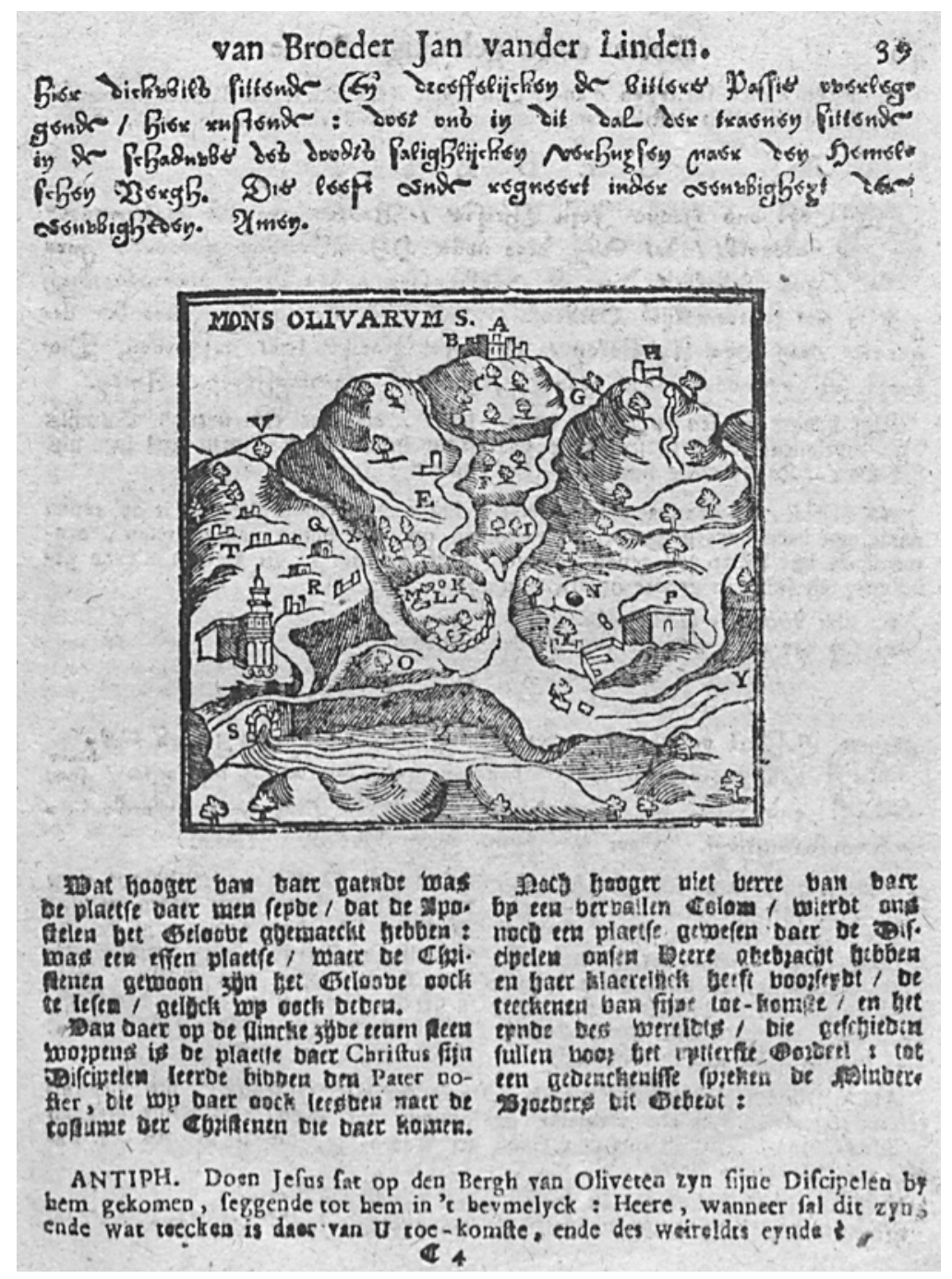

Figure 1. Mount of Olives, Heerlycke ende geluckige reyse, p. 39.

such books were urged to appropriate the picture by following the order of letters and to imagine themselves as part of the depicted scene (cf. DeKoninck 2005; Melion et al. 2015). The Heerlycke ende geluckige reyse was based on the same model, since young readers were urged to use the letters to navigate through texts and images, and to make their own mental image of Jerusalem. In this way, the reading practices materialized in Van der Linden's Heerlycke ende geluckige reyse invite the reader to imagine different spatialities, such as the page and an imagined place outside this page. In common with the adult pilgrims, the youngsters both read and observe places in order to explore and internalize them. But since their observational activities are restricted to the place of the book itself, the children's type of travelling is an imaginative process, deriving from paper experiences and resulting in an inner development. In much the way Stock suggests, the experience of travel is bounded by the medium itself and by the readers' experiences and imaginations. The youngsters' travelling is, in the end, a process of reading, and functions as a stepping stone to inner growth and mental reflection rather than physical movement. 


\section{How Young Readers Became Young Travelers}

In eighteenth-century youth literature, the mental travelling on paper, which Van der Linden's book invites readers to do, was replaced by empirical travelling. As a result of the Enlightened pedagogical ideal of empirical-based and curiosity-driven learning, travelling became an important tool for children's education - less a spiritual process than a practice of experiencing, observing, and discovering places. Following Jean-Jacques Rousseau's conception of children as curious and searching cats carefully examining new environments (Rousseau [1769] 1979, 125), pedagogue Jan Floris Martinet attributed an inquisitive nature to children and characterized them as strangers in an unknown world they aim to discover (Martinet 1793, 180). He therefore advised parents to offer their children travel experiences rather than clothing or golden valuables: "a walk to a countryseat they don't know, to a village, or a town; or, when they are older, a trip through another province" (ibid., 190) ${ }^{7}$. In the children's magazine De vriend der kinderen [The Children's Friend] trips were explicitly connected to the satisfaction of curiosity, the discovery of new knowledge, and - not least - physical and intellectual freedom. During a trip, children are freed from their daily commitments, move "fit and free," and thus explore an open space where they can learn (Vriend der Kinderen 1799, III, 139-140). ${ }^{8}$

This educational climate put books in a difficult position: learning was held to be the effect of empirical, sensory, and spatial experiences instead of instructional books. Rousseau, in his Emile from 1762, even described books as "the instruments of their [the children's] greatest misery" (Rousseau [1769] 1979, 116). Since the senses are the only accurate basis of reason, he considered book knowledge and reading as "the plague of childhood": "Our first masters of philosophy are our feet, our hands, our eyes. To substitute books for all that is not to teach us to reason. It is to teach us to use the reason of others" (ibid., 25, 116). So according to Rousseau, books did not align with the Enlightenment's pedagogical ideals of active and experiential learning, since they limited instead of increased children's agency to develop themselves as autonomous, knowledgeable humans.

However, children's books did actually serve several functions within educational travel practices. First of all, book and reading practices contributed to the children's development as travelers. According to Antony de Winter's A,B,C, boek [A, B, C, Book], 1750, for example, the development of reading skills is rewarded by "zoete-koek" (gingerbread) and will result in social and economic success: the educated child will grow up to be a sailor trading in exotic food in the East Indies. The opening poem refers to the depicted ship "The Swan," in the woodcut towed by a swan (fig. 2). Young readers could connect this visualized swan to their "future selves". After their reading education, they will be skilled travellers who explore and dominate the oversea world.

Secondly, books were used to promote travel activities. The Dutch politician and author Willem de Perponcher explicitly urges his readers to travel in his Nieuwe aardryksbeschryving voor de Nederlandsche jeugd (New Geography for Dutch Youth, 1784), since travelling was the foundation of all geographical and environmental knowledge. According to De Perponcher, children won't be able to understand maps and images before they have empirically discovered "towns, villages, lands, roads, canals, rivers, the sea and the mountains" (De Perponcher 1784, 2). ${ }^{9}$ A schoolmaster who merely shows the map of Europe, won't help his pupils to recognize places: "He asked them: what, actually, is the Sea? For the very reason that the first pupil hesitated,

\footnotetext{
${ }^{7}$ Original Dutch text: “eene wandeling naar eene hun onbekende Buitenplaats, naar een Dorp, naar eene Stad; of zijn zij grooter, een toertje door eene Vaderlandsche Provincie."

${ }^{8}$ Original Dutch text: "Niets zeker verblijdt den kinderen meer dan kleine plaizier-reisjes. Van hun kleine bezigheden eens ontslagen te zijn, zich eens frisch en vrij te bewegen, de nieuwsgierigheid en groote verwachting van 't gene zij zullen hooren of zien, de onderscheiden aanzigten en streken die zij zullen aantreffen."

${ }^{9}$ Original Dutch text: "steeden, dorpen, landen, weegen, vaarten, rivieren, ... de zee en de bergen."
} 


\section{'t Schip de Zwaan.}

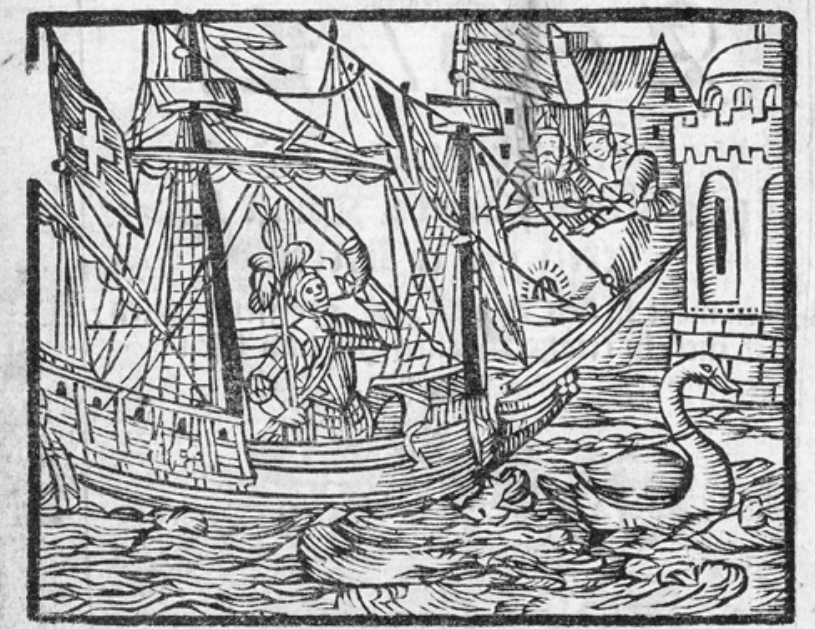

Dit Schip baat naar Baftinje tae / Sa Fongeng wilt u naarfíg |poe/ Oin wel te leeten in tit 2 aef $/$ Dan frugt ga ligtelijt 3 aete-frael /

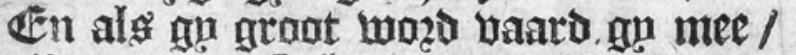
Illat aroute schepen ouer Zee Din altuerflambe leltfter goet /

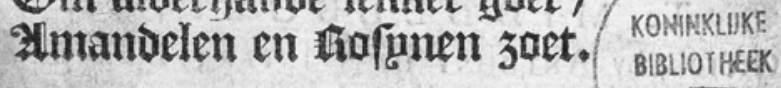

Figure 2. Een $A, B, C$, boek, bequaam ende profijtelijk voor de jonge kinderen om te leeren, opening poem.

the second one answered: Oh I know it! I know it! The See is a big piece of white paper, while he opened his eyes wide, and stretched his little hands as far as he could" (ibid.). ${ }^{10}$

The third - and within the scope of this paper most interesting - connection between reading and travelling arises when these two activities are merged: reading sometimes became a way of travelling. In his Onderwijs voor kinderen (Education for children, 1782), Willem de Perponcher explicitly represents reading as a mode of travelling. He introduces the young nobleman "Fleetfoot" ("snelvoet"), who was overtaken by the desire to travel, "to examine far and distant places and countries" (ibid., 369-370). ${ }^{11}$ His restlessness, however, led him to visit places without really observing and exploring them. In Sack's words, he drew "attention to the sense of space," without having the experience of places (Sack 1997, 16). When he went back home, and all people asked him for his observations, he had nearly nothing to say, since he just flew through places. People laughed - such a fruitless attempt to examine the world! - after which Fleetfoot saw his own error. He decided to make his trip once again, slowly and carefully, aiming to observe and explore everything in great detail.

\footnotetext{
${ }^{10}$ Original Dutch text: “. . zeeker leermeester, die, na alles wat men op de kaart van Europa vindt, aan zyne leerlingen, by herhaaling, te hebben aangeweezen en doen nazeggen, hun eindelijk vroeg; maar wat is nu eigentlyk de Zee? en daar de een wat aarselde, van den anderen ten antwoord kreeg; $\mathrm{O}$ ik weet het wel ! ik weet het wel ! de Zee is een groot stuk wit paper; teevens groote oogen makende, en de handjes zoo wyd van een strekkende, als hy kon."

${ }^{11}$ Original Dutch text: "Jonker snelvoet, die groote lust had om te gaan reizen, dat is verre afgeleegene plaatsen en landen te gaan bezien.”
} 
The narrator, in his turn, addresses himself to his readers, making an explicit comparison between Fleetfoot's travelling and the children's reading:

What happened to this traveller, my children, will also happen to such pupils who don't learn with stillness and don't pay enough attention to what they read in their books or what was told by teachers; such pupils who instead always want to go forward, always ask for the next thing, in order to see something new. Proceeding the end of a book or some lessons, they are not able to repeat it, and don't learn anything from it: they flew through their book, as the young man Fleetfoot flew through countries, and they couldn't reap the fruits of it. (Ibid., 371-372) ${ }^{12}$

According to the narrator, both reading and travelling are ways of learning, and share a need for close observation. "Flying through" is just as bad in travel as in reading: you meet much without understanding and examining. Reading children should therefore use Fleetfoot as a warning: those who will read books without careful examination will be ridiculed and need to restart their reading again. In this way, De Perponcher urges his young readers to turn their reading into a mode of travelling, and thus to use this reading to explore and experience new places.

To stimulate this intended process of "travelling by reading," children's book authors introduced several narrative techniques stimulating children to become travelers themselves, at least in their imaginations. Jan Floris Martinet's Katechismus der natuur (Catechism of Nature, 17781779) took the form of a long walk through different parts of the country, set out to observe and discuss natural phenomena. The book consists of the conversations of the walking pupil and its teacher: this pupil observes his environment, turns his observations into knowledge, and asks questions. The reader is able to internalize these perceptions, questions and words, and thus to travel along with his peer pupil. Arianne Baggerman introduces the neologism "walk-reading" (in Dutch: "looplezen") to characterize this textual strategy (Baggerman 2002).

While Katechismus der natuur merely consists in dialogues, in Christian Gotthilfs Salzmann's Reizen der kweekelingen van Schnepfenthal (Travels of Schnepfenthal's pupils, 1800; translated from the German book Reisen der Zöglinge zu Schnepfenthal, 1799), a narrator appears in his role as a travel guide and teacher. By regularly addressing the readers, he merges the narrative and readers' world. Even though he recognizes the distance between these two entities ("I wish that you once saw this," Salzmann 1800, $42^{13}$ ), he explicitly integrates the conversations with his readers into his fictional reality: he takes a rest in order to have a small talk together and continues his way only afterwards. To explain this theoretically, the narrator put the time in the narrative on hold, encouraging his readers to approach their own environment as a curious traveler.

Allow me, little readers, to pause a few moments near these new tiled roofs, and to have a small conversation with you.

My little readers!

I don't know where you live, but live where ever you are. As you definitely live in a certain place, investigate this place with attention, take notice of what's on the ground, what's growing from it, what's to be found around you, what people round you are doing! You will definitely find something useful.

Now we will travel farther. (Salzmann 1800, 27-28) ${ }^{14}$

\footnotetext{
${ }^{12}$ Original Dutch text: "Even zoo nu, myne kinderen, als het met deezen reiziger ging, gaat het ook met zulke leerlingen, die niet met bedaardheid leerende, en niet genoeg agt slaande, op 't geen zy, in de boeken, leezen, of hun leermeester hun verklaart, altyd slegt voor uit willen, en altyd maar naar 't volgende vragen, om weer wat nieuws te zien. Aan 't einde van het boek of van de lessen gekomen, weeten zy 'er niets van na te vertellen, en zyn 'er ook geen stip wyzer door geworden; maar hebben hun boek, even als jonker snelvoet zyne landen door gevloogen, en kunnen 'er ook even weinig vrugt van trekken."

${ }^{13}$ Original Dutch text: "Ik wenschte, dat gij het eens gezien had".

${ }^{14}$ Original Dutch text: "Veroorloof my, kleine Lezers! dat ik bij deeze nieuwe pannendaken eenige oogenblikken blijve stilstaan, en een klein gesprek met u houde. / Lieve kleine lezers! / Waar gijlieden woont, weet ik niet; maar woont waar het ook mag wezen: zo woont gij zeker op eene plaats; onderzoekt deeze plaats met aandagt, geef agt, op dat geene wat in den grond
} 
Moreover, Salzmann stimulates his readers to model themselves on the characters: when the fictional travelers have their meal, readers are invited to enjoy some delicious food as well (Salzmann 1800, 74). Salzmann's young readers, we may conclude, are encouraged to become travel participants themselves.

So while Jan van der Linden's Heerlycke ende geluckige reyse combined different typefaces and images in order to highlight the book's physical quality and to turn the book in a legible material place, eighteenth-century children's book authors introduced several narrative techniques stimulating young readers to travel along with the travelers and to accept their fictional journey as a reality (literary scholars define this process as the "willing suspension of disbelief" [Tomko 2015]). By emulating travelers, children consider their process of "reading about" places as a process of "seeing" places. As an effect, such travel stories suggest that children can experience and construct their own places by their practice of "travel-reading". But at the same time, since they served as a substitute for the empirical trip, the books relieved young readers of the obligation to explore the outside world empirically.

\section{Campe's Robinson Crusoe: Learning to Experience Places by Reading Books}

This ideal of emulating travelers involved two risks which were often discussed by eighteenth-century pedagogical thinkers, who realized that "emulation could easily go astray if not properly moderated" (O'Malley 2008, 132). In her Guardian of Education, Sarah Trimmer explained that a child's reading of Daniel Defoe's famous travel story Robinson Crusoe required supervision and regulation, since it once happened that two little readers run away and planned to embark a ship and discover an island (O'Malley 2008, 131-132; O'Malley 2012, 25-26). These juvenile readers merged their processes of "reading about" and "seeing" in such a radical way, that they decided to follow the empirical activity of "seeing." Children should be prevented from such dangerous effects of direct emulation. At the same time, however, a mere passive consumption of the book should be avoided as well. Processes of "reading about" and "seeing" places have to be combined in such an advanced way that young readers were stimulated to develop an explorative learning style that could be practiced within their own environment.

Joachim Heinrich Campe'sRobinson der Jüngere (1779-1780), translated into Dutch under the title Handleiding tot de natuurlyke opvoeding of Robinson Crusoë [Manual on the natural education or Robinson Crusoe], 1780-1781, was developed to serve this purpose. The German philanthropist Campe was directly inspired by Rousseau's suggestion to use Robinson as a fictional peer for children. While Rousseau created a hierarchical relationship between empirical experiences and media representations, and rejected the use of books in pedagogical practices, he indeed recommended Robinson Crusoë as a useful tool for children. This novel - of Robinson who was shipwrecked, stayed on his own on an island, and survived in the wild by using his own senses - was to be read by Rousseau's pupil Emile, who models himself on Robinson, in order to analyze and observe an unknown world.

This novel ... will be both Emile's entertainment and instruction .... I want it to make him dizzy; I want him constantly to be busy with his mansion, his goats, his plantations; I want him to learn in detail, not from books but from things, all that must be known in such a situation; I want him to think he is Robinson himself, to see himself dressed in skins, wearing a large cap, carrying a large saber. (Rousseau [1769] 1979, 184)

To facilitate this intended process of identification, Campe decided to adapt the original story for adults into a frame narrative for children: father, his daughter Charlotte, some other children and two adult friends read and discuss Robinson's story during thirty evenings (cf. Peterson 1992;

ligt, wat 'er op groeid, wat rond om u te vinden is, wat de menschen, die rond u woonen verwerken! gij zult zeker iets vinden, dat u van nut kan zijn. / Nu zullen wij verder reizen.” 
Koller 1991; Liebs 1977; Stach 1970; Zantop 1997). Campe's intervention was inspired by the upcoming tradition of Enlightened youth literature in Western-Europe: many more children's books published at the time were shaped as domestical conversations between parents and children (influential examples are Louise d'Epinay's Conversations d'Emilie, 1774, and Marie-Elisabeth de la Fite's Entretiens, drames et contes moraux, a l'usage des enfans, 1778). Such didactical conversations were often set up to discuss collectively consumed stories, books and plays (cf. Jeanne-Marie Le Prince de Beaumont's Magasin des Enfants, 1756, as an early trendsetter) (Brown 2007, chap. 3). Campe's adaptation follows this current trend, and as such functions as a theatrical performance, as Andrew O'Malley analyzed:

In its very layout, organized as a script with different speaking parts and containing what amount of stage directions (parenthetical, italicized descriptions of the family's actions), Campe's version of the Crusoe story has a strong affinity to the printed theatrical script. ... As a form, the familial dialogue invites the participation of children and turns principle and precept into lived experience, albeit heavily mediated and scripted. (O’Malley 2012, 31, cf. O’Malley 2008, 135)

As an effect of this performative form, the subject of the original Robinson story slightly changed: it transformed "Defoe's novel of triumphant individualism into a lesson in social responsibility through the medium of theatrical performance" (O’Malley 2008, 141). Matt Erlin also stated that the frame narrative Campe added to Defoe's novel allowed Campe to criticize the fetishization of goods which was stimulated by Defoe's original (as well as other books at the time): "By always attaching the man-made objects in the novel to their production history, the author simultaneously roots them to a particular function and purpose" (Erlin 2006, 368).

Campe's adaptation became one of the most successful German literary hits from the eighteenth century (Peterson 1992, 65). The German edition went through more than a hundred reprints within a century (Wegehaupt 1991, 80-83), and was translated in almost every European language (Peterson 1992: 65-67). Although the French Le Nouveau Robinson (1785) and the English New Robinson Crusoe (1788) - which was made from the French version - were mostly studied (Brown 2007, 153; O’Malley 2012; Blamires 2009, 23-38; Raven 2002, 727), recent scholarship also paid some attention to nineteenth-century translations into Yiddish, Hebrew, Finnish, Malay and Tagalog (Guillermo 2012; Garrett 2002; Shavit 1992; Taivalkoski-Shilov 2015), and travel stories that followed Campe's frame tale structure (O'Malley 2008; O’Malley 2012). The Dutch translation Handleiding tot de natuurlyke opvoeding of Robinson Crusoë, made by an anonymous translator, has remained understudied for the most part: it was only briefly discussed in studies on Dutch youth literature or Dutch Robinsonades, while its international context was mostly neglected (Staverman 1907, 150; Parlevliet 2009, 194-196; Buijnsters 1989, 211 212; Broos 1984, 39). This lack of international scholarly attention is remarkable, since this was the first translation of Robinson der Jüngere which was created outside the German countries (Campe has already translated his own book into English, for German children who wanted to increase their English language skills: Robinson the Younger 1781-1782, cf. Blamires 2009, 26).

Although the Dutch edition introduced a different title and some Dutch geographical names (Rotterdam instead of Hamburg; the Maas instead of the Elbe) and Dutch children's names (Willem instead of Gottlieb; Kootje instead of Frizchen), the translation was quite faithful. The edition O'Malley used in his didactical analysis - the English New Robinson Crusoe (1788) - deviated more from the original, especially in the first part of the book. As an effect of these differences, the Dutch (and German) edition more explicitly invites readers to imitate the fictional children. By means of this imitation process, young readers learn how to use their reading process as a way to experience places, and how to implement practical knowledge in their own world.

During the opening scene, which was lacking in the English version, the (extended) family seated near the apple tree - a situation lively depicted by textual as well as visual means. While the English translation opened by a picture of Robinson on his island, the only copperplate the Dutch book 


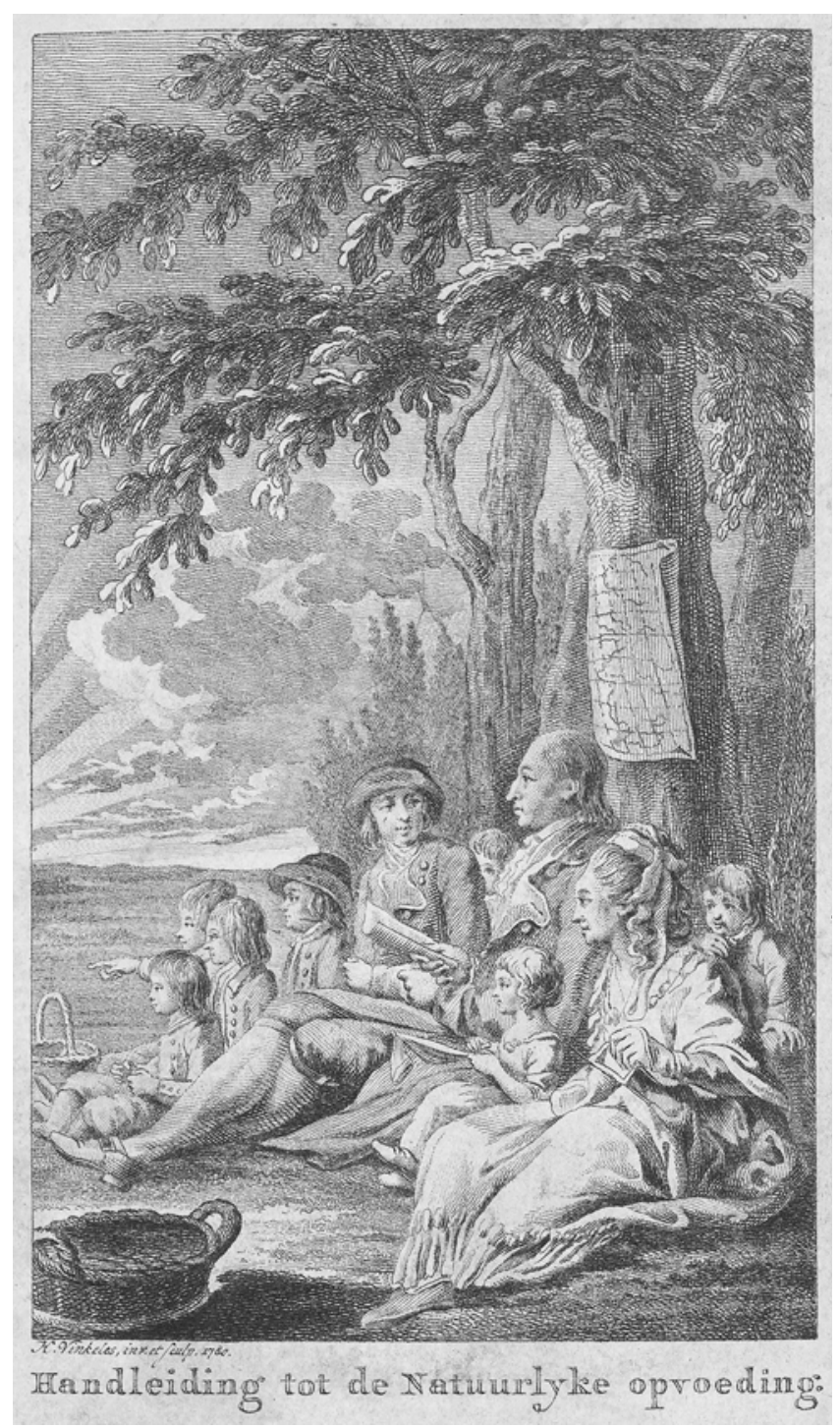

Figure 3. Campe, Handleiding tot de natuurlyke opvoeding of Robinson Crusoë, p. $\pi 1 \mathrm{r}$

contains, depicts the readers' travel guides: the children (fig. 3). The reader catches them when they are listening to Robinson's story, told by father who holds the book in his hand. Children and adults are settled in the garden, since father prefers a direct - unmediated - observation of the natural world: "it would be a pity to see such a nice evening through glasses" (Campe 1780-1781, Introduction). ${ }^{15}$ All protagonists line up and observe the natural environment right before them - one of the children even points its finger to highlight this collective observation process. The meaningful opening scene makes young readers aware of a radical merging of reading ("reading about"), observing ("seeing") and travelling within Campe's Robinson Crusoe, and thus presents reading as an unmediated practice of seeing places.

So, in comparison to the travel stories discussed in the previous section, in which youngsters were invited to join the experience of travelling, young readers of Campe's travel book do not model themselves upon the traveler (Robinson), but upon the children who consume

\footnotetext{
${ }^{15}$ Original Dutch text: "het zou jammer weezen, een' zo bekoorlyken avond slechts door de glaazen te aanschouwen."
} 
Robinson's adventures within their own environment. These children, in their turn, emulate Robinson by imitating his behavior and appearance. They follow, for example, Robinson's method of determining the length of months. As the father explains, Robinson calculated using his knuckles: "if you want, I can teach you this as well" (Campe 1780-1781, 88). Jan carefully imitates Robinson's trick, concluding that January contains thirty-one days (ibid., 88-89). ${ }^{16}$ Klaas, to give another example, follows Robinson's production of a game bag (ibid., 95-96). When he arrived the next evening, with his handmade bag and "a proud step," he is like Robinson, as mother says: "I had almost taken you for the real Robinson" (ibid., 98). ${ }^{17}$ Emulating Robinson, the children develop into agents who actively shape and create their own environment. Young readers, following the depicted children, are invited to do the same, as Charlotte explicitly applauds this type of modeling: "It is good, children, to imitate such things. Because whenever you might land on an unpeopled island, you know beforehand what to do" (ibid., 96). ${ }^{18}$

By means of this gradual didactical model, reading stories is presented as a way of reading, seeing, and travelling to places, while the children's travelling is simultaneously restricted by structured frames and guiding characters who in fact remove the need to undertake empirical travels. So, by introducing such narrative techniques to turn reading into a kind of travelling, the children's books both stimulated and hampered empirical travel practices. Rather than going along with travelers, young readers are stimulated to adapt place-making-skills to their own daily world, as the fictional children do as well. In this way, they become aware of their capacity to experience and appropriate (nearby) places, in order to become their own knowledgeable self. In order to facilitate this process of knowledge construction, Campe not only developed his frame tale model, but also a gradual learning pathway within his series of travel books for children.

\section{Knowledgeable Selves}

While the international reception of Robinson der Jüngere has received quite some scholarly attention, international editions of Campe's other travel books for children are hardly studied (except for Blamires 2009). Just as Robinson der Jüngere, Campe's other travel stories were translated into Dutch a year after the original, and together developed a gradual knowledge process, now accessible for young Dutch readers. In his prefaces, Campe explicitly introduces his travel books as successive steps ("trappen") within a process of knowledge acquisition. In Robinson Crusoë, the focus is on moral and practical knowledge: Robinson explores his natural environment to investigate how to produce flaxen threads and weave them into gamebags for transporting food. The Ontdekking van America, geschikt ter aangenaame ... leezing voor kinderen (The Discovery of America, suitable for a pleasant reading by children, 1782; original German title: Die Entdekkung von America, 1781-1782), Campe's second book and shaped by the same frame tale structure as his Robinson Crusoe, communicates basic geometric and geological knowledge: Columbus, for example, is shown using a plumb line to measure distance while sailing. In Campe's Eerste reis ter ontdekking in het Noorden (First journey for discovering the North, 1786; original German title: Gemälde des Nordens, 1785), physical knowledge was represented as well. Willem Barentsz and his sailors, for example, read their environment in order to understand the geographical and natural characteristics of the polar region.

In the case of frame narratives, the acquisition of knowledge is structured and guided within several levels of the text. Knowledge is not only created by the way travelers (such as Robinson and Columbus)

\footnotetext{
${ }^{16}$ Original Dutch text: "zo gy wilt, zal ik u dat ook leeren.”

${ }^{17}$ Original Dutch text: "Den volgenden avond, toen het gezelschap op de gewoonelyke plaats by elkanderen gekomen was, kwam KLAAS met eene weitasch, door hem zelven vervaardigd, met een' fieren tred aanwandelen, en trok daardoor de oogen van allen tot zich. In de plaats van den zonnescherm had hy van de keykenmeid eene zeef geleend, die hy op een' stok boven zyn hoofd droeg. Zyne geheele houding was statig en deftig. MOEDER, Braaf, KLAAS, dat heb je wel gemaakt! Het scheelde weinig, of ik had u voor den rechten ROBINSON aangezien."

${ }^{18}$ Original Dutch text: "Dat is goed, Kinderen, dat gy zulks namaakt. Want zo gy ooit eens op een eiland mogt komen, daar geene menschen zyn; dan weet gy al, hoe gy doen moet."
} 
read their places, but also by characters who (re)read these travelers' places. By their questions, evaluations, and observations, these fictional characters add new knowledge to the knowledge produced in the travelers' world itself. When Jan has been told that Robinson departed without parental permission, he strongly condemns this impudent deed, while "Friend B." asks to feel some pity for his foolishness as well (Campe 1780-1781, 8): moral knowledge about obedience and proper education is here produced within the children's instead of Robinson's world (ibid., 8, 16). Moreover, the children's requests for further clarification and explanation creates additional knowledge within their world and thus makes it available for the readers. When father tells about Robinson's ship at the "mouth of the Theems," "Friend B." explains, following Kootje's request: "the Theems is a river" and "the place where the river flows out in the sea, is called its mouth" (ibid., 16). ${ }^{19}$ And when Robinson met a "Guinea sailor" and Kootje asked for the meaning of this word, Gerrit showed the country in his pocket atlas, while father explained that "Guinea sailors" sailed to conduct trade (ibid., 21).

Fictional characters such as Jan, Gerrit, and Kootje not only gain knowledge by discussing and questioning the way travelers read their environment; the children also explore their own places along with the travelers' place. For example, Jan explains the workings of a vulcano by introducing a recognizable parallel from the children's nearer environment: "Have you never seen, when bricklayers throw cold water upon unslaked lime, how this lime immediately begins to bubble and boil?" (ibid., 201) ${ }^{20}$

Father, in his turn, suggests doing an experiment to better understand the vulcano's working (ibid., 202). Campe's children perform such experiments to gain knowledge from their own empirical space, in interaction with Robinson's place. In Campe's Ontdekking van America, Frederik, for example, needs to understand how Columbus turns his observations of the sky into knowledge. Father demonstrates this knowledge process to Frederik by using the ceiling of a room as a substitute for Columbus's heaven. Father and Frederik turn their room into a place to read in order to gain knowledge.

FATHER. Come with me to the large room! - So! Consider the ceiling of this room with careful attention, and observe the several ornaments which have been worked into it.

FREDERIK. Done!

FATHER. Now I will bind your eyes; then I will lead you back and forth in this room, and will turn you around several times, so that you will not know where you are any more. (The Father does just what he had said he was going to do.) Now lean your head backwards, so that when I remove the cloth, you will see nothing other than the ceiling. Thus! - And now (while removing the cloth) look upwards, and tell me, if you are able, in which corner of the room are we now?

FREÊRIK. In the corner by the organ.

FATHER. How do you know that?

FREERIK. Because here, just above me, there is a plaster rose, which I had noticed before.

FATHER. See, by observing the ceiling, you are able to know, where you actually are. What do you think now? Wouldn't sailors be just as able to discover, in a similar way, in which part of the sea they are?

FREÊRIK. Oh yes! They just need to observe the sky, as I observe the ceiling, then they will see, by the stars, where they are. (Campe 1782, 47-48) ${ }^{21}$

\footnotetext{
${ }^{19}$ Original Dutch text: "De Theems is eene rivier, gelyk hier de Maas, en loopt niet verre van London in de Zee. De plaats, daar eene rivier zich in de Zee ontlast, word de mond derzelve genoemd."

${ }^{20}$ Original Dutch text: "Heb je niet gezien, als de metselaars koud water op ongebluschte kalk gieten, dat die alsdan terstond begint op te borrelen en te kooken."

${ }^{21}$ Original Dutch text: "VADER. Kom met my mee naar de grote zaal! - Zo! beschouw nu eens, recht met oplettendheid, de zoldering van dit vertrek, en merk op de verscheidene cieraaden, welke daaraan gemaakt zyn. / FREDERIK. Goed! / VADER. Nu zal $\mathrm{ik} u$ de oogen toebinden; ik zal $\mathrm{u}$ alsdan in dit ruim vertrek heen en weêr leiden, en $\mathrm{u}$ eenige maalen daarby omdraaijen, tot dat gy
} 
In this fragment, the child readers (outside the book) obtain their knowledge by 1) Columbus's reading of places, 2) Frederik's reading of Columbus's creation of places, and 3) Frederik's reading of his own environment. Passing through the different layers of the book and the successive steps in practical learning, readers were to develop into "knowledgeable youngsters." They were invited to train their own skills to travel, to observe places, and to turn observations into new knowledge. In this way, the narrative framework empowers children to read their own empirical world, following in the characters' footsteps, becoming agents of their learning process. But at the same time, the space for knowledge acquisition and interpretations is highly restricted. The literary and narrative techniques within the travel stories create a suggestion of agency, but are, most of all, instruments to guide the readers' shaping of a knowledgeable self.

\section{Conclusion}

Young readers of travel stories faced an intriguing paradox. On the one hand, the "journey" as a narrative line and motif transformed books from classical teaching instruments into dynamic places to discover, inviting children to follow the characters' travel practices. Their books served as emancipatory instruments facilitating the development of knowledge and the discovery of new places. But at the same time, they position children as subordinate to adults who prescribed the accessible knowledge by producing the books, and as such diminished the freedom to travel, to imagine, and to understand. This tension between children's agency and adults' guidance is fundamental to mediated learning practices in a more general way: books offered new spaces to explore and new knowledge to consume, but simultaneously affected how youth were able to become knowledgeable.

All travel stories analyzed in this article - from the seventeenth and eighteenth century, written in Dutch or translated from other languages - show this tension between explorative learning and strict guiding. It was, however, possible to trace a development in the way these two characteristics interacted. In the popular seventeenth-century Heerlycke ende geluckige reyse, young readers were invited to travel within the book, which was presented as a place that covers material pages to observe as well as imagined places to read about. In Heerlycke ende geluckige reyse, the travel motif most of all functioned as the steppingstone to a devotional reading process, which facilitated mental rather than physical movement. The (late) eighteenth century, which saw the rise of a more extensive genre of travel literature for children and a general trust in the educational potency of travel practices, shifted from an inner to a more empirical mode of travelling. Expanding narrative techniques invited readers to travel along with characters within the text. Instead of highlighting the book as a material place, the eighteenth-century travel stories rather raised the suggestion that they offered unmediated observations and travel experiences, as if reading about places was equal to seeing places. Although they turned reading into a mode of travelling, and thus relieved young readers of the obligation to explore the outside world empirically, they simultaneously invited children to develop their own competencies to construct places and to become active, explorative and knowledgeable selves.

Did such travel stories actually succeed in the shaping of such explorative youngsters? While it is very difficult to reveal what real effects these books had on their readers, the diary

volstrekt niet meer weeten zult, waar gy eigenlyk zyt. / (De Vader deed, gelyk hy had gezegd.) / Leg nu uw hoofd achterover, zodanig, dat als ik den doek zal weg doen, gy niets zult zien, dan de zolder. Zo! - En nu (hem den doek afneemende) zie nu opwaards, en zeg my, zo gy kunt, in welken hoek van de zaal wy thans zyn? / FREÊRIK. In den hoek by het orgel. / VADER. Hoe weet gy dat? / FREÊRIK. Om dat hier, juist boven my, de gestukadoorde roos is, welke ik te vooren wel heb opgemerkt. / VADER. Zie, dus kunt gy uit de beschouwing van den zolder weeten, op wat plaats gy eigenlyk zyt. - Wat denkt gy nu; zouden de zeevaardenden niet ook wel op eene soortgelyke wyze kunnen ontdekken, in welke streek der zee zy zyn? / FREÊRIK. O ja! Zy behoeven slechts den hemel te aanschouwen, gelyk ik de zoldering, dan kunnen zy 't wel aan de sterren zien, waar zy zyn." 
of Gerrit Jan Mulder helps us to assume that travel stories indeed functioned as instruments to shape searching and active people. During the 1880s, Mulder reflected on his childhood at the beginning of the nineteenth century. Although he emphasized that he learned more from walking around and observing the world than from reading books (Mulder 1883, 10-11), Robinson Crusoe was presented as an exception to this rule. When he was a child, he time and again consulted his Robinson edition - probably an illustrated edition of Campe's Handleiding tot de natuurlyke opvoeding of Robinson Crusoë printed in the early nineteenth century $^{22}$ - which largely impacted his development (ibid., 40-41). Mulder did not use the book as a steppingstone to long travels: during his childhood, he rather explored the gardens of nearby countryhouse Zijdebalen (ibid., 38-40). The book was, instead, a friend to emulate, and an instrument to develop an active and open-minded self: as he explained, Robinson Crusoe saved him from a narrow-minded, passive life (ibid., 41). ${ }^{23}$

\section{References}

\section{Primary sources}

Cambon-van der Werken, Margareta Geertruid de. 1790. De kleine Klarissa [The little Klarissa]. The Hague: I.F. Jacobs de Age.

Campe, Joachim Heinrich. 1780-1781. Handleiding tot de natuurlyke opvoeding of Robinson Crusoë, geschikt ten dienste der jeugd [Treatise to the natural education of Robinson Crusoe, suitable for youth]. Amsterdam: Mens, Jansz., A., Amsterdam.

Campe, Joachim Heinrich. 1782. De ontdekking van America, geschikt ter aangenaame en nuttige leezing voor kinderen en jonge lieden [The discovery of America, suitable for children's and youngsters' pleasant and useful reading]. Amsterdam: Widow of J. Dóll.

Campe, Joachim Heinrich. 1786. Eerste reis ter ontdekking in het Noorden [The first journey for discovering the North]. In: Reisbeschryvingen voor de jeugd [Travel descriptions for youth]. Amsterdam: Widow of J. Dóll.

Erasmus, Desiderius. 2006. Opvoeding [Education]. Translated and edited by J. De Landtsheer and B. Breij. Amsterdam: Athenaeum - Polak \& Van Gennip.

Linden, Jan van der. S.d. Heerlycke ende gheluckighe reyse, naer het H. landt ende de stadt van Jerusalem [Glorious and fortunate journey to the Holy land and the town of Jerusalem]. Antwerp: Widow of Hieronymus Verdussen. Copy: University of Antwerp, MAG-P 12.1313 .

Martinet, Johannes Florentius. 1793. Huisboek voor vaderlandsche huisgezinnen [House book for native families]. Amsterdam: Johannes Allart.

Mulder, Gerardus Johannes. 1883. Levensschets van G.J. Mulder door hem zelven geschreven en door drie zijner vrienden uitgegeven [Outline of G.J. Mulder's life, written by himself and published by three of his friends]. Utrecht: Van der Post.

Perponcher, Willem de. 1784. Nieuwe aardryksbeschryving voor de Nederlandsche jeugd [New description of the earth for Dutch youth]. Utrecht: Widow of J. van Schoonhooven.

Perponcher, Willem de. 1782. Onderwys voor kinderen [Education for children]. Utrecht: Widow of J. van Schoonhooven. Rousseau, Jean-Jacques. [1769] 1979. Emile: Or, on Education. Translated by Alan Bloom. Basic Books.

Salzmann, C.G. 1800. Reizen der kweekelingen van Schnepfenthal [Journeys of pupils from Schnepfenthal]. Amsterdam: M. Schalekamp.

Vriend der kinderen[Friend of children]. 1799. Volume III. Haarlem: C.H. Bohn en zoon.

Winter, Anthony de. 1750. Een A,B,C, boek, bequaam ende profijtelijk voor de jonge kinderen om te leeren [An A,B,C book, suitable and useful for young children to learn from]. Middelburg: Anthony de Winter.

\footnotetext{
${ }^{22}$ Mulder 1883, p. 40: in Mulder's edition of Robinson Crusoe, largely illustrated, Robinson's cave was lacking. Mulder could have read the illustrated edition of Campe's adaptation which was published in 1815 (when Mulder was thirteen years old). Cf. the review in the Vaderlandsche Letteroefeningen 1816, 90-92.

${ }^{23}$ Original Dutch text: "Zonder Robinson Crusoe, dien groote, dien uitvoerige, ware ik misschien mijn leven lang gebleven bekrompen en fletsch van aard, en niets ondernemende."
} 


\section{Secondary sources}

Ansell, Richard. 2018. "Reading and Writing Travels: Maximilien Misson, Samuel Waring and the Afterlives of European Voyages, c.1687-1714.” The English Historical Review 133:565: 1446-1477.

Baggerman, Arianne. 2002. “'Looplezen' rond 1800. Kinderen en het Boek der Natuur." ['Walk-reading' around 1800. Children and the Book of Nature] Literatuur zonder leeftijd 58:188-209.

Baggerman, Arianne. 2004. "Keuzecompetentie in tijden van schaarste en overvloed. Het debat rond jeugdliteratuur voor en na Hiëronymus van Alphen (1760-1840)." [Selection competence in times of scarcity and abundance. The debate about youth literature before and after Hiëronymus van Alphen (1760-1840)] In: Een groot verleden voor de boeg. Cultuurhistorische opstellen voor Joost Kloek [A huge history in front. Cultural-historical essays for Joost Kloek], edited by Gert Jan Johannes, José de Kruif and Jeroen Salman, 17-37. Leiden: Primavera Press.

Baggerman, Arianne, and Rudolf Dekker. 2005. Kind van de toekomst. De wondere wereld van Otto van Eck (1780-1798) [Child of the future. The wondrous world of Otto van Eck (1780-1789)]. Amsterdam: Wereldbibliotheek.

Barend-van Haeften, Marijke. 1992. Oost-Indië gespiegeld. Nicolaas de Graaf, een schrijvend chirurgijn in dienst van de VOC [The East-Indies reflected. Nicolaas de Graaf, a writing chirurgeon in service of the VOC]. Zutphen: Walburg Pers.

Beening, André. 1996. “Wat zegt je van zulke helden. De overwintering op Nova Zembla in 19 ${ }^{\text {de }}$-eeuwse schoolboeken'. [What do you say about such heroes? The hibernation on Nova Zembla in 19th-century school books] Spiegel Historiael 31:408-413.

Bekkering, Harry. 2003. “Gullivers Reizen voor kinderen: vooral over dwergen en reuzen." [Gulliver's Journey's for children: especially about gnomes and giants] Literatuur zonder leeftijd 60:70-86.

Blamires, David. 2009. Telling Tales. The Impact of Germany on English Children's Books 1780-1918. Cambridge: Open Book Publishers.

Broos, Tom. 1984. "Robinson Crusoe and the Low Countries.” Dutch Crossing: Journal of Low Countries Studies 8:32-43.

Brown, Penelope. 2007. A Critical History of French Children's Literature. Hoboken: Taylor and Francis.

Brown, Penelope. 2009. “'Girls Aloud': Dialogue as a Pedagogical Tool in Eighteenth-Century French Children's Literature.” The Lion and the Unicorn 33-2:202-218.

Buijnsters, Piet J. 1989. "Nederlandse kinderboeken uit de achttiende eeuw." [Dutch children's books from the eighteenth century] In De hele Bibelebontse berg. De geschiedenis van het kinderboek in Nederland en Vlaanderen van de middeleeuwen tot heden [The huge 'Bibelebonts' mountain. The history of the children's book in the Netherlands and Flanders from the Middle Ages until today], edited by Harry Bekkering, 168-228. Amsterdam: Querido.

Carroll, Jane Suzanne. 2012. Landscape in Children's Literature. New York and London: Routledge.

Cecire, Maria Sachiko, Hannah Field, Kavita Mudan Finn, and Malini Roy, eds. 2015. Space and Place in Children's Literature, 1789 to the Present. Surrey: Ashgate.

Certeau, Michel de. 1984. "Chapter IX: Spatial stories." In The practice of everyday life, 115-130. Berkeley, Los Angeles, and London: University of California Press.

Christensen, Nina. 2009. "Lust for Reading and Thirst for Knowledge: Fictive Letters in a Danish Children's Magazine of 1770." The Lion and the Unicorn 33-2:189-201.

Conley, Tom. 1996. Self-Made Map: Cartographic Writing in Early Modern France. Minneapolis, US: University of Minnesota Press.

Conley, Tom. 2011. Errant Eye: Poetry and Topography in Early Modern France. Minneapolis, US: University of Minnesota Press.

Cook, Harold. 2007. Matters of Exchange: Commerce, Medicine, and Science in the Dutch Golden Age. New Haven: Yale University Press.

Crang, Mike, and Nigel Thrift, eds. 2000. Thinking Space. New York and London: Routledge.

Cresswell, Tim. 2004. Place: A Short Introduction. Oxford: Blackwell.

Cutter-Mackenzie, Amy, Philip G. Payne, and Alan Reid. 2014. Experiencing Environment and Place through Children's Literature. New York and London: Routledge.

DeKoninck, Ralph. 2005. Ad Imaginem: Status, Functions et usages de l'image dans la literature spirituelle jesuite du XVIIe siècle. Geneva: Droz.

Dietz, Feike. 2016. "Met fictieve peers op zoek naar de waarheid: Fictie als didactisch instrument in Verlicht-religieuze catechismussen van Samuel van Emdre (1781-1798)." [Searching for Truth with Fictional Peers: Fiction as a Didactic Instrument in the Enlightenment Religious Catechisms of Samuel van Emdre (1781-1798)] Bijdragen en Mededelingen Betreffende de Geschiedenis der Nederlanden 131(3):3-25.

Doughly, Terri and Dawn Thompson. 2011. Knowing Their Place? Identity and Space in Children's Literature. Cambridge: Cambridge Scholars Publishing.

Enenkel, Karel, Paul van Heck, and Bart Westerweel, eds. 1998. Reizen en reizigers in de Renaissance: eigen en vreemd in oude en nieuwe werelden. [Journeys and travelers in the Renaissance: the 'own' and the 'strange' in old and new worlds] Amsterdam: Amsterdam University Press.

Erlin, Matt. 2006. "Book Fetish: Joachim Heinrich Campe and the Commodification of Literature." Seminar: A Journal of Germanic Studies 42(4):355-376.

Frasca-Spada, Marina, and Nick Jardine, eds. 2000. Books and the Sciences in History. Cambridge: Cambridge University Press. 
Fyfe, Aileen. 2000. "Young Readers and the Sciences." In Books and the Sciences in History, edited by Marina Frasca-Spada and Nick Jardine, 278-290. Cambridge: Cambridge University Press.

Garrett, Leah. 2002. “The Jewish Robinson Crusoe.” Comparative Literature 54(3):215-228.

Gelderblom, Arie Jan. 2006. "Beestachtige observaties. Dieren in de Nederlandse (post)koloniale literatuur 1600-2000." [Bestial observations. Animals in Dutch (post)colonial literature 1600-2000] Indische Letteren 21(4):198-213.

Grenby, Matthew O. 2011. The Child Reader, 1700-1840. Cambridge: Cambridge University Press.

Griffiths, Paul. 1996. Youth and Authority. Formative Experiences in England, 1560-1640. Oxford: Clarendon Press.

Guillermo, Ramon. 2012. "Southeast Asian Robinsonades: A Study on the Translation of Joachim Heinrich Campe's Robinson der Jüngere (1779-1780) into Tagalog (Ang Bagong Robinson, 1879) and Bahasa Melaya (Hikayat Robinson Crusoë, 1875)." In Understanding Confluences and Contestations, Continuities and Changes: Towards Transforming Society and Empowering People. The Work of the 2009/2010 API Fellows, 177-192. Bangkok: The Nippon Foundation.

Harkness, Deborah. 2007. The Jewel House: Elizabethan London and the Scientific Revolution. New Haven, London: Yale University Press.

Harms, Roeland. 2012. "Populaire literatuur in een nieuw jasje. Adaptatiestrategieën in narratieve centsprenten." [Popular literature in a new shape. Adaptation strategies in narrative penny prints] Spiegel der Letteren 54(2):227-257.

Harms, Roeland. 2014. "Pioniers en avonturiers. De overlevering van literaire klassiekers in centsprenten." [Pioneers and adventurer. The tradition of literary classics in penny prints] In Sterke verhalen: vijf eeuwen vertelcultuur, edited by Jeroen Salman, 115-133. Nijmegen: Vantilt.

Koller, Hans-Christoph. 1991. "Erziehung zur Arbeit als Disziplinierung der Phantasie: J. H. Campes Robinson der Jüngere im Kontext der philanthropischen Pädagogik.” In Vom Wert der Arbeit: zur literarischen Konstitution des Wertkomplexes 'Arbeit' in der deutschen Literatur (1770-1930), edited by Harro Segeberg, 41-76. Tübingen: Niemeyer.

Kusukawa, Sachiko. 2012. Picturing the Book of Nature: Image, Text and Argument in Sixteenth-Century Human Anatomy and Medical Botany. Chicago: University of Chicago Press.

Lefèbvre, Henri. [1974] 1991. The Production of Space. Translated by Donald Nicholson-Smith. Oxford: Blackwell.

Liebs, Elke. 1977. Die pädagogische Insel: Studien zur Rezeption des "Robinson Crusoe" in deutschen Jugendbearbeitungen. Stuttgart: Metzler.

MacKenzie, Louisa. 2011. The Poetry of Place. Lyric, Landscape, and Ideology in Renaissance France. Toronto: University of Toronto Press.

Martin, Henri Gérard. 1928. Fénelon en Hollande. Amsterdam: H.J. Paris.

Meijer Drees, Marijke. 1997. Andere landen, andere mensen: de beeldvorming van Holland versus Spanje en Engeland omstreeks 1650. [Other lands, other people: the representation of Holland versus Spain and England around 1650] Den Haag: SDU.

Melion, Walter, Wietse de Boer, Karl A.E. Enenkel. 2015. Jesuit Image Theory. Leiden: Brill.

Miert, Dirk van, ed. 2013. Communicating Observations in Early Modern Letters (1500-1675): Epistolography and Epistemology in the Age of the Scientific Revolution. London: Warburg Institute Colloquia.

Ogilvie, Brian W. 2006. The Science of Describing. Natural History in Renaissance Europe. Chicago: University of Chicago Press.

O’Malley, Andrew, 2008. “Acting out Crusoe: Pedagogy and Performance in Eighteenth-Century Children's Literature.” The Lion and the Unicorn 33(2):132-145.

O’Malley, Andrew. 2012. Children's Literature, Popular Culture, and Robinson Crusoe. New York: Pallgrave Macmillan.

Parlevliet, Sanne. 2009. Meesterwerken met ezelsoren. Bewerkingen van 'literaire klassiekers' voor kinderen 1850-1950. [Masterpieces with dog-ears. Adaptations of literary classics for children 1850-1950] Dissertation Groningen.

Parlevliet, Sanne. 2014. "Bring up the Children: National and Religious Identity and Identification in Dutch Children's Historical Novels 1848-c. 1870.” History of Education 43(4):468-486.

Peterson, Brent O. 1992. “Robinson Crusoe Shifts Paradigms: Joachim Heinricht Campe’s Robinson der Jüngere." In Robinson Crusoe in the Old and New Worlds, edited by Ton J. Broos, Jelle Kingma and Anton Bossers, 65-79. Groningen: Ann Arbor.

Raven, James. 2002. “An Antodote to the French?: English Novels in German Translation and German Novels in English Translation 1770-99." Eighteenth-Century Fiction 14(3/4):715-734.

Roeper, V.D., and G.J.D. Wildeman. 1996. Reizen op papier. Journalen en reisverslagen van Nederlandse ontdekkingsreizigers, kooplieden en avonturiers. [Travelling on paper. Journals and travel reports of Dutch discoverers, merchant and adventurers] Amsterdam: Vereeniging Nederlandsch Historisch Scheepvaartmuseum.

Sack, Robert David. 1997. Homo Geographicus: A Framework for Action, Awareness, and Moral Concern. Baltimore: Johns Hopkins University Press.

Salman, Jeroen. 2000. “'Om tot presentjes aan kinderen te geven'. Het kinderboek in de achttiende-eeuwse boekhandel.” ['For children's presents'. The children's book in the eighteenth-century book shop] In: Tot volle waschdom. Bijdragen aan de geschiedenis van de kinder- en jeugdliteratuur, edited by Berry Dongelmans, Netty van Rotterdam, Jeroen Salman, and Janneke van der Veer, 75-86. Den Haag: Biblion.

Secord, James. 1985. "Newton in the Nursery: Tom Telescope and the Philosophy of Tops and Balls, 1871-1838." History of Science 23:127-151. 
Shavit, Zohar. 1992. "Literary Interference between German and Jewish-Hebrew Children's Literature during the Enlightenment: The Case of Campe." Poetics Today 13(1):41-61.

Schmitt-Maa $\beta$, Christoph, Stefanie Stockhorst, and Doohwan Ahn, eds. 2014. Fénelon in the Enlightenment: traditions, adaptations, and variations. Amsterdam: Rodopi.

Smith, Pamela H. 2004. The Body of the Artisan: Art and Experience in the Sientific Revolution. Chicago: Chicago University Press.

Smith, Pamela H. 2009. "Science on the Move: Recent Trends in the History of Early Modern Science." Renaissance Quarterly 62(2):235-275.

Smith, Pamela H., and Tonny Beentjes. 2010. "Nature and Art, Making and Knowing: Reconstructing Sixteenth-Century Life-Casting Techniques.” Renaissance Quarterly 63:28-179.

Smith, Pamela H. and Benjamin Schmidt. 2007. Making Knowledge in Early Modern Europe: Practices, Objects, and Texts, 1400-1800. Chicago and London: University of Chicago Press.

Stach, Reinhard. 1970. "Robinson der Jüngere als pädagogisch-didaktisches Modell des philanthropistischen Erziehungsdenkens.” Ratingen, Wuooertal, Kastellaun: A. Henn Verlag.

Staverman, W.H. 1907. Robinson Crusoe in Nederland. Een bijdrage tot de geschiedenis van den roman in de XVIIIe eeuw. [Robinson Crusoe in the Netherlands. A contribution to the history of the novel in the 18th century] Groningen: M. de Waal.

Stock, Brian. 1993. "Reading, Community and a Sense of Place.” In Place, Culture, Representation, edited by James Duncan and David Ley, 314-328. London and New York: Routledge.

Taivalkoski-Shilov, Kristiina. 2015. "Friday in Finnish: A character's and (re)translators' voices in six Finnish retranslations of Daniel Defoe's Robinson Crusoe." Target: International Journal of Translation Studies 27(1):58-74.

Tally, Robert T. 2011. Geocritical Explorations: Space, Place, and Mapping in Literary and Cultural Studies. Basingstoke: Palgrave Macmillan.

Tally, Robert T. 2013. Spatiality: The New Critical Idiom. London and New York: Routledge.

Tomko, Michael. 2015. Beyond the Willing Suspension of Disbelief. Poetic Faith from Coleridge to Tolkien. Bloomsbury: Bloomsbury Publishing.

Toorn, A. van, M. Spies and S. Hoogerhuis. 1989. "Christen Jeugd, leerd Konst en Deugd.” [Christian Youth, learn Skills and Virtues] In De hele Bibelebontse berg. De geschiedenis van het kinderboek in Nederland en Vlaanderen van de middeleeuwen tot heden [The huge 'Bibelebonts' mountain. The history of the children's book in the Netherlands and Flanders from the Middle Ages until today], edited by Harry Bekkering. Amsterdam: Querido.

Vaderlandsche Letteroefeningen[National Exercises in Letters]. 1816. Amsterdam: G.S. Leeneman van der Kroe and J.W. IJntema.

Verhoeven, Gerrit. 2004. “'Brought Together at Great Effort': The Place of Author, Publisher and Reader in the Genesis of the Early Modern Travel Guide.” Quaerendo 34:240-253.

Wasser, Ben. 2014. Dit is de pelgrimage van het Heilig Land en daaromtrent: Bloemlezing uit de reisverslagen van Jeruzalemgangers uit de Nederlanden, 1450-1650. [This is the pilgrimage to the Holy Land and around there. Anthology of the travel reports of Jerusalem travelers from the Netherlands, 1450-1650] Hilversum: Verloren.

Wegehaupt, Heinz. 1991. Robinson und Stuwwelpeter. Bücher für Kinder aus fünf Jahrhunderten. Berlin: Deutsche Staatsbibliothek in der Stiftung Preussischer Kulturbesitz.

Zantop, Susanne. 1997. Colonial Fantasies: Conquest, Family, and Nation in Precolonial Germany, 1770-1870. Durham: Duke University Press.

Feike Dietz is Assistant Professor Early Modern Dutch literature at Utrecht University. She is currently working on a research project on the relationship between early modern literature and knowledge production, specifically focusing on the way books for youths taught advanced literacy and knowledge skills. She is also one of the project leaders of the NWO Vrije Competitie Project Language Dynamics in the Dutch Golden Age, in which literary and linguistics strategies of language variation are analysed from an interdisciplinary perspective.

Cite this article: Dietz, Feike. 2019. "Mediated education in early modern travel stories: How travel stories contribute to children's empirical learning," Science in Context 32:193-212. doi:10.1017/S026988971900019X 